\title{
ОРГАНІЗАЦІЯ ТА ПРОВЕДЕННЯ ПРАКТИК ЯК КЛЮЧОВИЙ ЧИННИК ФОРМУВАННЯ ПІЗНАВАЛЬНОЇ ДІЯЛЬНОСТІ СТУ ДЕНТІВ ПЕДАГОГІЧНИХ СПЕЦІАЛЬНОСТЕЙ
}

\author{
Тернавська Т. А. Організація та проведення практик як ключовий чинник формування \\ пізнавальної діяльності студентів педагогічних спеціальностей. \\ Стаття присвячена обгрунтуванню організації та проведення практик. Визначено особливості \\ формування пізнавальної діяльності студентів педагогічних спеціальностей у процесі практичної \\ підготовки.
}

Ключові слова: пізнавальна діяльність, практична підготовка.

Тернавская Т. А. Организация и проведение практик как ключевой фактор формирования познавательной деятельности студентов педагогических специальностей.

Статья посвящена обоснованию организации и проведения практик. Определены особенности формирования познавательной деятельности студентов педагогических специальностей в процессе практической подготовки.

Ключевые слова: познавательная деятельность, практическая подготовка.

Ternavskaya T. A. Organization of practice as a key factor in the formation of cognitive activity of students of pedagogical specialties.

The article is dedicated to the process of organization and conducting practices. It is defined the peculiarities of forming cognitive activity to pedagogy students while preparing them to practice.

Key words: cognitive activity, preparing to practice.

Навчальна та виробнича практики студентів педагогічних спеціальностей $\epsilon$ невід'ємним складником процесу підготовки фахівців у вищому навчальному закладі. Проводиться на базі сучасних загальноосвітніх шкіл, дошкільних закладів, закладів освіти. Дидактичною метою практичної підготовки студентів $\epsilon$ закріплення знань, одержаних в процесі навчання, оволодіння навичками вміннями та засобами організації майбутньої професійної діяльності, формування професійного вміння приймати самостійні рішення у певних виробничих умовах, а також збирання фактичних та впровадження методичних матеріалів у процесі виконання курсової та дипломної роботи.

Для викладачів вищої школи актуальною є проблема створення сприятливих умов для формування пізнавальної діяльності у процесі практичної діяльності студентів (насамперед на старших курсах). Фактично йдеться про те, щоб навчити та стимулювати студентів вчитися і впроваджувати придбані вміння та навички в професійній діяльності, i це часом важливіше, ніж озброєння їх конкретними предметними знаннями. Це неможливо зробити без певного обсягу знань психолого-педагогічного та логікометодологічного характеру, в тому числі і розробки освітньо-професійних програм, відповідної побудови навчальних планів для студентів ВНЗ, змістових характеристик дисциплін, що вивчаються та новітніх технологій їх викладання.

Аналіз результатів моніторингу якості надання освітніх послуг у галузі вищої освіти, вимог ринку праці до вмінь випускників вищих навчальних закладів, звернень та пропозицій роботодавців 3 питань забезпечення якості професійної підготовки випускників показує, що в умовах ринкової економіки ситуація з організацією практичної підготовки у вищих навчальних закладах суттєво погіршилась. У результаті цього між вимогами ринку праці та практичними результатами освітньої діяльності вищих навчальних закладів утворився відчутний розрив, що призводить до численних нарікань 3 боку споживачів освітніх послуг та роботодавців, зокрема на відсутність навичок 
практичної роботи за обраним напрямом або спеціальністю, знань сучасних технологій та обладнання підприємств, їх діючої нормативної бази i, як наслідок, зростання часу адаптації випускників на первинних посадах, ускладнення працевлаштування і зниження престижу вищої освіти загалом [2].

Практична підготовка студентів $є$ обов'язковим компонентом професійної підготовки. Проходження такої підготовки необхідне для здобуття кваліфікаційного рівня та має на меті набуття студентами професійних умінь і навичок. У бюджеті навчального часу виробнича (педагогічна) практика становить близько 20-25\% всього навчального часу. Ефективність практики забезпечується зв'язками між вищим навчальним закладом та відповідним закладом для проведення практики [4, с. 155].

А. Вербицький пропонує контекстний підхід до організації навчання, згідно 3 яким розмежовується три базових форми діяльності студентів і безліч перехідних. До базових належать: навчальна діяльність академічного типу з провідною роллю лекції й семінару; квазіпрофесійна (ділові ігри та інші ігрові форми); навчально-професійна (виробнича практика, «реальне» дипломне проектування). Він зазначає, що «послідовна трансформація однісї форми діяльності навчання в іншу все більше наближається до форм організації професійної діяльності, але не втрачає своїх педагогічних властивостей і можливостей» [1, с. 98].

Метою статті є теоретичне обгрунтування особливостей організації та проведення практичної підготовки студентів педагогічних спеціальностей як ключового чинника формування пізнавальної діяльності.

Залежно від конкретного рівня підготовки, спеціальності чи спеціалізації практика може бути: польова; туристична; позакласна та позашкільна (пасивна); навчально-виховна (пасивна); психологічна в закладах освіти; педагогічна в оздоровчих таборах; педагогічна в закладах освіти тощо [5].

Зміст та послідовність практики визначається наскрізною програмою практики, що розробляється випускаючою кафедрою згідно 3 навчальним планом для кожної спеціальності з урахуванням вимог освітніх стандартів зі спеціальності та затверджується керівником вищого навчального закладу.

Зміст наскрізної програми практики повинен відповідати нормативно-правовим документам України щодо практики студентів, кваліфікаційній характеристиці фахівця, навчальному плану спеціальності. На основі цієї програми розробляються робочі програми відповідних видів практики, які підписуються завідувачами випускаючих кафедр і затверджуються Вченою радою вищого навчального закладу.

По кожному етапу практики програми практики мають містити рекомендації щодо видів і форм перевірки знань, умінь і навичок, яких мають набути студенти. Кафедри також можуть розробляти й інші методичні документи, що сприятимуть досягненню високої якості проведення практики студентів.

Положенням про здійснення практичної підготовки, яке розробляється у кожному вищому навчальному закладі, передбачено зміст практики, бази практик, організація та керівництво практикою, функції при організації практики. Перелік усіх видів практики для кожної спеціальності або спеціалізації, їх форми, тривалість і терміни проведення визначаються в навчальних планах.

Згідно $з$ освітньо-професійною програмами підготовки бакалавра (галузь знань «0101 Освіта») для спеціальності «Початкова освіта» в нормативній частині навчального плану відводиться 27,5 кредитів на цикл практичної підготовки. У варіативній - 13 кредитів всього 40,5; для спеціальності «Філологія (англійська)» в нормативній частині навчального плану відведено 12 кредитів на цикл практичної підготовки, в варіативній - 3 кредити - всього 15 [3].

Згідно з навчальним планом підготовки спеціаліста, для спеціальності «Початкова освіта» в нормативній частині навчального плану відводиться 13,5 кредитів на цикл 
практичної підготовки; для спеціальності «Мова і література (англійська)» в нормативній частині навчального плану відводиться 10 кредитів на цикл практичної підготовки.

Педагогічна практика є однією з важливих підсистем загальної системи професійної підготовки студентів педагогічних спеціальностей. Вони проводяться в умовах максимально наближених до професійної діяльності. У процесі практики можна усвідомити науково-теоретичні основи роботи вчителя та вихователя, осмислити закономірності і принципи розвитку, навчання й виховання, оволодіти професійними уміннями і навичками, досвідом практичної діяльності, активно включитися в процес національного виховання підростаючого покоління. Проходження практики в умовах освітніх закладів сприяє формуванню свідомого ставлення кожного студента до педагогічної діяльності, поглибленому вивченню загальнокультурних i психологопедагогічних дисциплін, розвитку педагогічних здібностей, вихованню необхідних особистісних якостей, які забезпечать успішне виконання функцій вчителя та психолога закладів освіти.

Метою педагогічної практики є оволодіння студентами сучасними методами та формами організації навчально-виховного процесу в галузі їх майбутньої професії, формування у майбутніх учителів початкової школи та психологів професійних умінь та навичок, виховання потреби систематично поповнювати свої знання та творчо застосовувати їх у практичній діяльності. Власне на практиці студенту надається можливість визначити правильність обраної галузі діяльності, з'ясувати міру відповідності особистих якостей необхідних для професії вчителя.

Основними завданнями педагогічної практики є:

- поглиблення й закріплення теоретичних знань студентів, здобутих під час вивчення методик та дисциплін психолого-педагогічного циклу;

- формування й закріплення основних професійно-педагогічних умінь, навичок, досвіду відповідно до вимог стандартів вищої педагогічної освіти і кваліфікаційної характеристики бакалавра;

- розвиток у майбутніх учителів педагогічної свідомості і професійно важливих якостей особистості, розвиток професійної культури;

- забезпечення основами застосування педагогічних технологій i педагогічною технікою;

- навчання методам вивчення та аналізу педагогічного досвіду і застосування його в педагогічній діяльності;

- формування творчого педагогічного мислення, індивідуального стилю професійної діяльності, дослідницького підходу до неї;

- профорієнтація і профвиховання, розвиток і закріплення інтересу до педагогічної діяльності та роботи з дітьми, профдіагностика придатності до педагогічної професії;

- формування умінь здійснювати диференційований та індивідуальний підхід до дітей, оволодіння студентами методикою вивчення учнів та дитячого колективу;

- розвиток потреби в педагогічній самоосвіті і постійному самовдосконаленні;

- вивчення сучасного стану навчально-виховної роботи в різних типах шкіл, передового і нетрадиційного досвіду.

Отже, практична підготовка студентів педагогічних спеціальностей виконує ряд функцій: адаптаційну, навчально-виховну, розвивальну та діагностичну.

Особливу увагу слід звернути на оптимізацію практичної підготовки майбутніх педагогічних працівників, зокрема створенню ефективної мережі баз практик, здійснити ретельний відбір шкіл, профтехучилищ регіону для проведення педагогічних практик із залученням до цієї роботи найдосвідченіших вчителів-методистів.

У процесі навчально-виховної діяльності науково-методичним радам вищих навчальних закладів доцільно переглянути навчальні плани задля відновлення та подальшого підвищення статусу практичної підготовки; оптимізувати розроблення та впровадження у навчальний процес наскрізних та безперервних програм практик, нові 
системи практичної підготовки студентів та періодично оновлювати їх, відповідно до вимог сучасного освітнього процесу; створювати систему ранньої адаптації випускників на первинних посадах, шляхом дозволу навчання студентів старших курсів за індивідуальним графіком, у зв'язку із працевлаштуванням за спеціальністю, та проведенням «Ярмарку кар’єри».

\section{Література}

1. Вербицкий А. А. Активное обучение в высшей школе : контекстный подход / Андрей Александрович Вербицький. - М. : Высш. шк., 1992. - 123 с. 2. Лист МОН 1/9-93 від 07.02.2009 р. «Про практичну підготовку студентів» / І. О. Вакарчук. - К, 2009. - С. 1. 3. Освітньо-професійна програма підготовки бакалавра (в частині розподілу навчального часу за циклами підготовки, переліку та обсягу нормативних дисциплін галузі знань «0101Освіта», напрямку підготовки 6.010102 «Початкова освіта») / керівн. розроб. Бондар В. І. - К. : НПУ ім. М. П. Драгоманова, 2009. 4. Педагогіка вищої школи : [навч. посіб.] / 3. Н. Курлянд, П. І. Хмелюк, А. В. Семенова та ін., / за ред. 3. Н. Курлянд. - 3-тє вид., перероб. і доп. - К. : Знання, 2007. - 495 с. 5. Положення «Про проведення практик студентів»: за станом на 28 вересня 2009 р. / підгот. Т. А. Тернавська. Кіровоград : ПВНЗ «СПІ Педагогічна академія», 2009. - 14 с.

УДК 371.13:316.647.5

I. C. Тишик, acniрант,

Кіровоградський державний педагогічний університет імені Волдимира Винниченка

\section{ДО ВИЗНАЧЕННЯ ПОНЯТТЯ «МІЖЕТНІЧНА ТОЛЕРАНТНІСТЬ» У ПРОЦЕСІ ПІДГОТОВКИ МАЙБУТНІХ ВИКЛАДАЧІВ}

Тишик I. С. До визначення поняття «міжетнічна толерантність» у процесі підготовки майбутніх викладачів.

У статті представлено аналіз понять «толерантність» та «міжетнічна толерантність», доведено важливість формування міжетнічної толерантності як одного 3 визначальних чинників професійного становлення майбутніх викладачів.

Ключові слова: толерантність, міжетнічна толерантність, міжетнічна взаємодія, особистість майбутнього викладача.

Тишик I. С. К определению понятия «этническая толерантность» в процессе підготовки будущих преподавателей.

В статье проанализировано значение таких понятий, как «толерантность» и «этническая толерантность», обосновывается важность формирования межэтнической толерантности как обязательного фактора профессионального становления будущего преподавателя.

Ключевые слова: толерантность, межэтническая толерантность, формирование личности будущего преподавателя.

Tyshyk I. S. To the definition of notion «interethnic tolerance» in the process of training of future teachers.

The article reveals theoretical analysis concepts «tolerance» and «ethnic tolerance». Based on the analysis of psycho-pedagogical literature discusses the importance of creating interethnic tolerance as one of the most important factors of professional development for future teachers.

Key words: tolerance, interethnic tolerance, interethnic interaction, the identity formation of future teacher.

Проблема побудови міжетнічних відносин є ознакою глобалізаційних процесів та соціокультурних реалій нашої держави. Незважаючи на те, що поняття «толерантність» і «міжетнічна толерантність» стали загальновживаними в галузі суспільних наук, вони й донині залишаються змістовно «розмитими». Входження України до Болонського процесу 